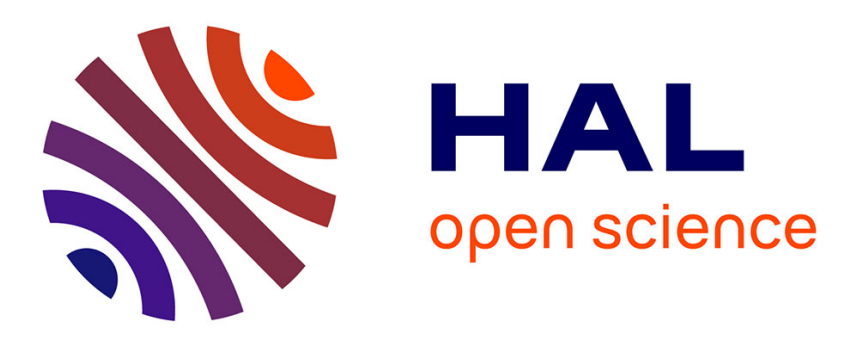

\title{
Idiopathic pulmonary arterial hypertension in a patient with pyruvate kinase deficiency and paravertebral extramedullary hematopoiesis
}

\author{
C. Bachmeyer, A. Khalil, K. Kerrou, R. Girot, V. Gounant
}

\section{- To cite this version:}

C. Bachmeyer, A. Khalil, K. Kerrou, R. Girot, V. Gounant. Idiopathic pulmonary arterial hypertension in a patient with pyruvate kinase deficiency and paravertebral extramedullary hematopoiesis. Annals of Hematology, 2008, 88 (6), pp.603-605. 10.1007/s00277-008-0644-z . hal-00535007

\section{HAL Id: hal-00535007 https://hal.science/hal-00535007}

Submitted on 11 Nov 2010

HAL is a multi-disciplinary open access archive for the deposit and dissemination of scientific research documents, whether they are published or not. The documents may come from teaching and research institutions in France or abroad, or from public or private research centers.
L'archive ouverte pluridisciplinaire HAL, est destinée au dépôt et à la diffusion de documents scientifiques de niveau recherche, publiés ou non, émanant des établissements d'enseignement et de recherche français ou étrangers, des laboratoires publics ou privés. 


\title{
Idiopathic pulmonary arterial hypertension in a patient with pyruvate kinase deficiency and paravertebral extramedullary hematopoiesis
}

\author{
C. Bachmeyer • A. Khalil • K. Kerrou • R. Girot • \\ V. Gounant
}

Received: 2 October 2008 / Accepted: 11 November 2008 / Published online: 29 November 2008

(C) Springer-Verlag 2008

\begin{abstract}
Dear Editor,
Pulmonary arterial hypertension (PAH) is defined as a sustained elevation of pulmonary arterial pressure to more than $25 \mathrm{mmHg}$ at rest or to more than $30 \mathrm{mmHg}$ during exercise, with a mean pulmonary-capillary wedge pressure and left ventricular end-diastolic pressure of less than $15 \mathrm{mmHg}$, leading to right ventricular dysfunction, congestive heart failure, and death [1]. PAH is a well-known complication in patients with hemoglobinopathies such as sickle cell disease and thalassemia. PAH is closely related to the hemolytic anemia. Nonhepatosplenic extramedullary hematopoiesis has been described in association with a wide variety of myeloproliferative diseases and hemoglobinopathies such as sickle cell disease and thalassemia [2]. It is due to increased renal excretion of erythropoietin secondary to anemia or hypoxia and can involve any organs
\end{abstract}

C. Bachmeyer $(\bowtie)$

Service de Médecine Interne, CHU Tenon,

4 rue de la Chine,

75020 Paris, France

e-mail: claude.bachmeyer@tnn.aphp.fr

\section{A. Khalil}

Service de Service de Radiologie, CHU Tenon (APHP),

Paris, France

\section{K. Kerrou}

Service de Médecine Nucléaire, CHU Tenon (APHP),

Paris, France

R. Girot

Service d'Hématologie, CHU Tenon (APHP),

Paris, France

V. Gounant

Service de Pneumologie, CHU Tenon (APHP),

Paris, France and tissues, including the mediastinum, pleura, lungs, and heart. In most cases, the diagnosis is fortuitous, and rarely, the lesions are symptomatic, displaying neurological signs, pleural effusion, cardiac tamponade, and dyspnea [2]. Pyruvate kinase (PK) deficiency is the most common cause of hereditary nonspherocytic hemolytic anemia, transmitted as an autosomal recessive condition, with classical features ranging from mild anemia to a transfusion-dependant disease [3]. We report in this paper a case of dyspnea indicating idiopathic PAH associated with paravertebral hematopoiesis in a patient with PK deficiency.

A 47-year-old man, current smoker, with PK deficiency diagnosed at birth requiring splenectomy at age 5 years and who denied any drug intake, was hospitalized in July 2007 for dyspnea on exertion [New York Heart Association (NYHA) class III] present for 1 month. On examination, he appeared healthy. A grade 3/6 systolic murmur was heard best in the pulmonary area. Mucocutaneous jaundice was found. The findings on laboratory testing of renal function, liver test function, and C-reactive protein, search for antinuclear antibodies and anti-extractable nuclear antibodies, and HIV testing were normal or negative. Hepatitis B virus serology was consistent with past immunization, and hepatitis $\mathrm{C}$ virus serology was positive, with a negative viral load. Other laboratory test results are indicated in Table 1. Arterial blood gas analysis showed $\mathrm{pO}_{2} 73 \mathrm{mmHg}$, $\mathrm{pCO}_{2} 34 \mathrm{mmHg}, \mathrm{pH} 7.43, \mathrm{SaO}_{2} 93 \%$ while breathing ambient air. Chest X-ray (Fig. 1) and computed tomography (CT) scan demonstrated paravertebral soft tissue masses extending from $\mathrm{T} 1$ to $\mathrm{T} 10$, with heterogeneous enhancement after contrast administration and main pulmonary artery enlargement at $43 \mathrm{~mm}$ without signs of thrombotic or embolic disease concordant with the ventilation-perfusion lung scan. Magnetic resonance imaging (MRI) displayed the paravertebral masses isointense on T1-weighted sequences, 
Table 1 Laboratory data

\begin{tabular}{lcl}
\hline Variable (unit) & Results & Reference range \\
\hline Pyruvate kinase activity $(\mathrm{IU} / \mathrm{gHb})$ & 3.0 & $11-41$ \\
Hemoglobin level $(\mathrm{g} / \mathrm{dl})$ & 8.4 & $12-18$ \\
Mean cell volume $(\mathrm{fl})$ & 125 & $80-100$ \\
Reticulocyte $\left(\times 10^{9} / \mathrm{l}\right)$ & 250 & $30-120$ \\
White blood cell $\left(\times 10^{9} / \mathrm{l}\right)$ & 17.5 & $4-10$ \\
Neutrophils $\left(\times 10^{9} / 1\right)$ & 11.1 & $1.5-7$ \\
Eosinophils $\left(\times 10^{9} / 1\right)$ & 1.1 & $0.03-0.7$ \\
Lymphocytes $\left(\times 10^{9} / 1\right)$ & 3.8 & $1.5-4$ \\
Monocytes $\left(\times 10^{9} / 1\right)$ & 1.2 & $0.1-1.0$ \\
Platelet $\left(\times 10^{9} / 1\right)$ & 777 & $150-400$ \\
Lactate dehydrogenase $(\mathrm{IU} / \mathrm{l})$ & 950 & $125-250$ \\
Bilirubin level $(\mu \mathrm{g} / \mathrm{l})$ & 88 & $<17$ \\
Haptoglobin $(\mathrm{g} / \mathrm{l})$ & 0.08 & $0.5-1.5$ \\
Ferritin $(\mu \mathrm{g} / \mathrm{l})$ & 1,200 & $25-200$ \\
Brain natriuretic peptide $(\mathrm{ng} / \mathrm{l})$ & 498 & $<100$ \\
\hline
\end{tabular}

slightly hyperintense on T2-weighted images with a discrete heterogeneous uptake of gadolinium (Fig. 2). A whole-body technetium sulfur colloid radionuclide scan (99mTc-SC) showed increase uptake of the tracer throughout the skeletal, the liver, and the paraspinal masses consistent with extramedullary hematopoiesis, confirmed on CT scanguided needle aspiration. Echocardiography found a high pulmonary arterial pressure at $80 \mathrm{mmHg}$, with right ventricular hypertrophy, increased right atrial dimension, and mild tricuspid regurgitation due to ruptured chordae tendineae of the posterior leaflet. Right heart catheterization displayed pulmonary capillary wedge pressure of $12 \mathrm{mmHg}$, mean pulmonary arterial pressure of $54 \mathrm{mmHg}$, right ventricular pressure of $67 \mathrm{mmHg}$, cardiac output of 7.931/ $\mathrm{mn}$, and cardiac index of $5.11 \mathrm{1} / \mathrm{mn} / \mathrm{m}^{2}$, and the test with inhaled nitric oxide was negative. Lung function tests showed vital capacity of $74 \%$ of the theoretical value,

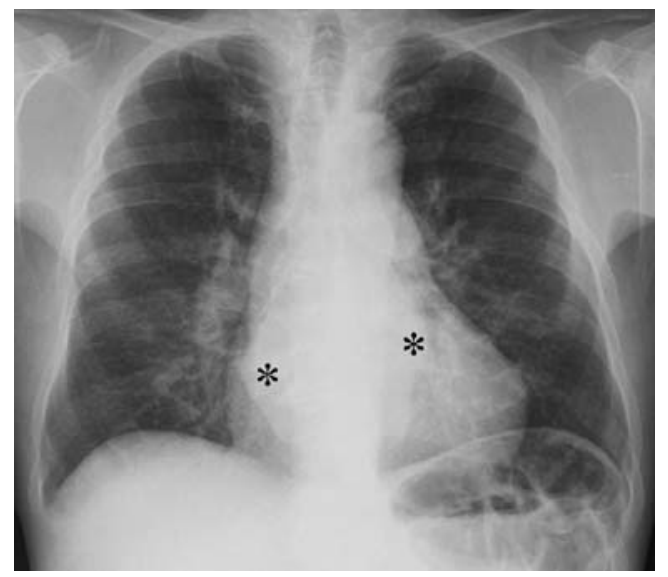

Fig. 1 Chest X-ray demonstrating a bilateral paravertebral mass (asterisk) and enlargement of the pulmonary artery trunk

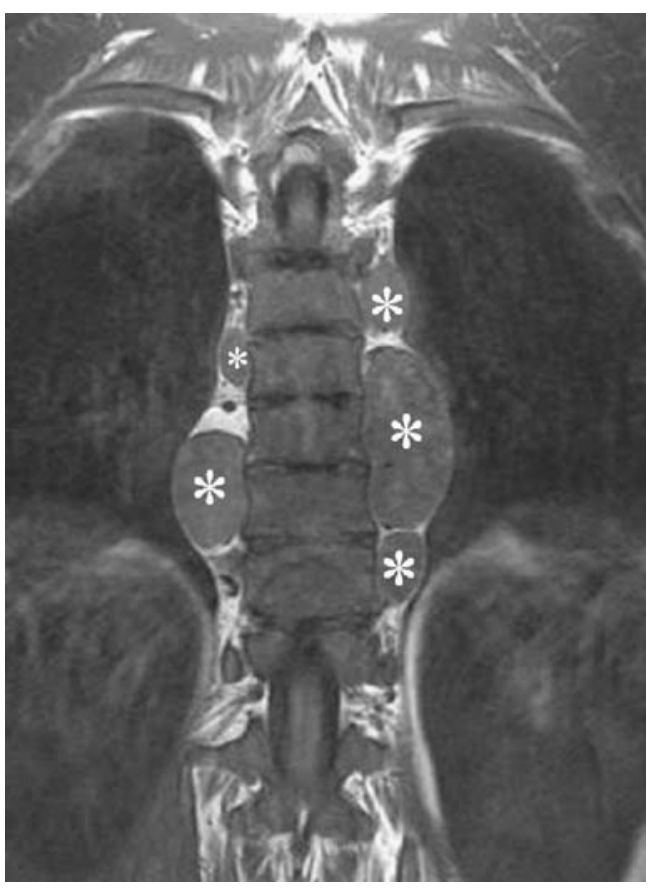

Fig. 2 Coronal spin echo T1-weighted MR image showing hyposignal of the vertebral bodies and paravertebral masses (asterisk)

forced expiratory volume in one second of $49 \%$, forced expiratory volume in one second/vital capacity of $53 \%$ partly reversible after betamimetics, and carbon monoxide transfer factor of $42 \%$. Fiberoptic bronchoscopy was normal, and bronchoalveolar lavage failed to detect hematopoietic cells. Treatment with oxygen, betamimetics, anticoagulants, and bosentan was given with relief of dyspnea (NYHA class II), decrease of mean pulmonary arterial pressure evaluated by right heart catheterization at $40 \mathrm{mmHg}$, and cessation of oxygen treatment.

Thoracic extramedullary hematopoiesis results usually in asymptomatic masses in the posterior mediastinum discovered during systematic chest X-ray [2]. Rarely, spinal cord compression, symptomatic pleural effusion, hemothorax, and pulmonary hematopoiesis have been described [2-4]. Diagnosis of extramedullary hematopoiesis may be suspected on clinical findings. CT scan with intravenous contrast injection shows unilateral or bilateral, smooth and lobulated with homogeneous enhancement. MRI demonstrates an isointense lesion on T1- and T2-weighted images with an intermediate enhancement after intravenous injection of gadolinium. The $99 \mathrm{mTc}-\mathrm{SC}$ colloid radionuclide scan shows increased tracer activity in the masses. Finally, CT-scan-guided needle biopsy allows a definite diagnosis but is not always necessary since the procedure carries the risk of hemorrhage.

In our patient, imaging was typical with extramedullary hematopoiesis. However, because of the rarity of this finding in patients with PK deficiency, a histological 
diagnosis was required. Indeed, only five cases of paravertebral masses due to extramedullary hematopoiesis have been reported in patients with PK deficiency [2, 4-7]. In all cases, an incidental finding led to the diagnosis, but spinal cord compression in one case [7]. Finally, treatment of extramedullary hematopoiesis is required only when complications occur, including blood cell transfusion, surgery, and low-dose radiotherapy.

Interestingly, in our patient, chest X-ray was performed because of dyspnea leading to the diagnosis of PAH and paraspinal masses related to extramedullary hematopoiesis. Since search for an underlying cause of this precapillary PAH was negative, idiopathic PAH was considered. Pathogenesis of PAH remained speculative in our patient. Indeed, a thromboembolic disease was unlikely. Of note, splenectomy may promote recurrent thromboembolic disease or in situ thrombosis [8], and such an event following splenectomy has been reported in an adult patient with PK deficiency [9]. Free hemoglobin caused by intravascular hemolysis could result in the consumption of nitric oxide, with subsequent $\mathrm{PAH}$, as demonstrated in sickle cell disease [10].

Extramedullary hematopoiesis developing in the wall of pulmonary arteries was also disputed.

Non-thromboembolic PAH seems unusual in patients with PK deficiency. However, a prospective study on PAH in patients with PK deficiency could be useful to assess its incidence.

\section{References}

1. Farber HW, Loscalzo J (2004) Pulmonary arterial hypertension. N Engl J Med 351:1655-1665. doi:10.1056/NEJMra035488

2. Koch CA, Li CY, Mesa RA, Tefferi A (2003) Nonhepatosplenic extramedullary hematopoiesis: associated diseases, pathology, clinical course, and treatment. Mayo Clin Proc 78:1223-1233

3. Zanella A, Bianchi P, Fermo E (2007) Pyruvate kinase deficiency. Haematologica 92:721-723. doi:10.3324/haematol.11469

4. Rutgers MJ, van der Lugt PJ, van Turnhout JM (1979) Spinal cord compression by extramedullary hematopoietic tissue in pyruvatekinase-deficiency-caused hemolytic anemia. Neurology 29:510-513

5. Schön HR, Emmerich B, Arnold H, Maubach PA, Becker K, Rastetter J (1984) Hemolytic anemia with pyruvate kinase deficiency presenting as paravertebral myelolipoma. Klin Wochenschr 62:133-137. doi:10.1007/BF01738704

6. Roder C, Dienemann H (2000) Extramedullary hematopoiesis as differential mediastinal space-occupying lesion diagnosis. Chirurg 71:1509-1512. doi:10.1007/s001040051253

7. Plensa E, Tapia G, Junca J, Perez R, Castella E, Marti S (2005) Paravertebral extramedullary hematopoiesis due to pyruvate kinase deficiency. Haematologica 90:e92

8. Jaïs X, Ioos V, Jardim C, Sitbon O, Parent F, Hamid A, Fadel E, Dartevelle P, Simonneau G, Humbert M (2005) Splenectomy and chronic thromboembolic pulmonary hypertension. Thorax 60:1031-1034. doi:10.1136/thx.2004.038083

9. Chou R, DeLaughery TG (2001) Recurrent thromboembolic disease following splenectomy for pyruvate kinase deficiency. Am J Hematol 67:197-199. doi:10.1002/ajh.1107

10. Jeffers A, Gladwin MT, Kim-Shapiro DB (2006) Computation of plasma hemoglobin nitric oxide scavenging in hemolytic anemias. Free Radic Biol Med 41:1557-1565. doi:10.1016/j. freeradbiomed.2006.08.017 